\title{
Implementation of Constructivism Learning Theory in Science
}

\author{
Dinelti Fitria $^{1)}$, Jamaris ${ }^{2)}$, Sufyarma ${ }^{3)}$ \\ ${ }^{1)}$ Program Studi Doktor Ilmu Pendidikan Pascasarjana Universitas Negeri Padang \\ ${ }^{2,3)}$ Universitas Negeri Padang \\ *Coresponding Author \\ Email : dineltifitria2603@gmail.com
}

\begin{abstract}
This study aims to identify and understand the implementation of constructivism learning theory in science. The method used in this study uses a library method or approach (library research). Data obtained through literature study. The results showed that constructivist teaching is based on the belief that learning occurs as learners are actively involved in a process of meaning and knowledge construction rather than passively receiving information. Teaching methods based on constructivist views are very useful to help students' learning. The following are practices derived from cognitive psychology that can help students understand, recall and apply essential information, concepts and skills. They are used to make lessons relevant, activate students' prior knowledge, help elaborate and organize information, and encourage questioning. Important concepts from this perspective are advanced organizers, analogies, and elaboration. Teaching science from a constructivist perspective aims to give students knowledge of science in such a way that they not only understand the concepts and principles of science, but also the significance of science learning
\end{abstract}

\section{Keywords: Constructivism learning Theory, Science}

\section{INTRODUCTION}

Science is what makes up the world and it would be able to know that would be by getting a real education in the studies of science. Science encompasses the systematic study of the structure and behavior of the physical and natural world through observation and experiment, and technology is the application of scientific knowledge for practical purposes. Then, science is a branch science whose focus of study is nature and processes that exist in it. Science as a system to understand the universe through controlled observation and experiment. Besides that, science is also a science relating to how to find outabout natural phenomena systematically, so science is not just mastery a collection of knowledge in the form of facts, concepts, or principles only but it is also a process invention. In science learning is very close to problemsolving process (Clair \& Bell, 2015), so if in learning science is optimal, then the solving process problems, critical thinking, communication, collaboration, and information literacy will achieved.

The conventional teaching-learning methods used in schools especially in science classroom encourages the students to memorize knowledge generally in the form of laws, formulae or theories and enforces them to reproduce as such in the examination. Constructivist approach in teaching at all levels of school is needed because the conventional pedagogical practices of teaching emphasize learning of answers more than exploration of questions, memory at the expense of critical thought, bits and pieces of information instead of understanding the context.

Constructivism theory asserts that knowledge can only exist in the human mind, and that the theory does not have to fit into the real world. Students will continually seek to derive their own personal mental model of the real world from their perception of that world. As they 
experience each new experience, students will continually update their own mental models to reflect the new information, and, therefore, will construct their own interpretations of reality.

\section{RESEARCH METHODS}

The method used in this study uses a library method or approach (library research), Literature study or literature can be interpreted as a series of activities that regarding the methods of collecting library data, reading and recording and processing materials research.

According to Zed (2003), there are at least four main characteristics that the author need to pay attention to, among others: First, that the author or researcher is dealing directly with the text or numerical data, not with direct knowledge from the field. Second, library data is "ready to use" means that the researcher does not go directly to the field because the researcher is dealing directly with data sources in the library. Third, that library data is generally a source of secondary, in the sense that the researcher obtains material or data from second hands and not data original from the first data in the field. Fourth, that the condition of the library data is not limited by space and time.

Based on the foregoing, the data collection in the research This is done by reviewing and/or exploring several journals, books, and documents that relevant to the research or study

\section{RESULTS AND DISCUSSION}

\section{Definition of Constructivism}

The word of constructivism is the active learning process in order to achieve the knowledge. It lays the learners as the key player of the learning process. In other word constructivism defines learning as the actively process to construct knowledge by learners while they are trying to make sense of their experience, learner form, elaborate and exercise mental structure until one is satisfied. In addition, constructivist teaching is based on the belief that learning occurs as learners are actively involved in a process of meaning and knowledge construction rather than passively receiving information. Learners are the makers of meaning and knowledge. Constructivist teaching establish critical thinking and creates motivated and independent learners. Cristie (2005) argues that constructivism is the learning theory which establish learning as the active process in order to achieve knowledge. Knowledge is constructed and shaped by experience. Constructivism leads one to achieve knowledge through his own experience. Moreover, it emphasizes on problem solving and understanding and the instructors are necessary to use authentic tasks, experiences, assessment also the content of subject presented holistically not in smaller parts.

Brooks and Brooks (1993) argued that there are some features or terms that dealing with constructivism learning theory such as student-centered, authentic, problem or project-based, cooperative, collaborative, inquiry-based, and so forth. Those features indicate that constructivism learning theory stand for the notion of active learning which integrates cooperative and collaborative strategy through which students are required to be more active in order to solve their problem collectively in group work.

\section{The Principles of Constructivism}

The key word of the principle of constructivism learning is being active to involve in terms of constructing knowledge by establishing group work and collaborating collectively. Constructivist educational principles that assert that learning is a situated, social, and 
collaborative activity in which learners are responsible for constructing their own knowledge by testing concepts based on their prior knowledge and experience (Bruner, 1996; Collins et al., 1989).

Twomey Fosnot (1989) defines constructivism by realizing the ideal four principles of learning. The first point is learning is determined by what we already know. The second point is the significant of elaborate new ideas or information; new ideas occur as we adapt and change our old ideas. The further point is learning designed to invent something new such as ideas rather than mechanically accumulating facts. The last is meaningful learning occurs through rethinking old ideas and coming to new conclusions about new ideas which conflict with our old ideas. Therefore, a productive constructivist classroom should consists of learnercentered, active instruction. For instance, in a classroom, the teacher provides students with experiences that allow them to hypothesize, predict, manipulate objects, pose questions, research, investigate, imagine, and invent. The teacher's role is to facilitate this process.

\section{Understanding constructivism learning theory}

In general there are three types of learning theories which are widely known. Those are: behaviorist; cognitive; and humanistic. Each of these theories has different perspective on how learning happens to human being. The behaviorist learning theory focuses its attention to how external factors influences learning process. The cognitive learning theory describes the mental function of human learning. Humanistic learning theory explains the role of motivation in individual development.

Constructivism is considered part of the cognitive learning theory which is closely related to other learning concepts such as discovery and meaningful learning. The use of constructivism approach in learning activities is aimed to maximize students' comprehension. (Cruickshank, 2006, p. 255). Constructivism approach view learning as a process of building knowledge and skills of the students. To build their own knowledge and skills, it is necessary for the students to interact with various type of learning materials which are relevant to the instructional objectives.

Brooks \& Brooks (1999) said that in a constructivist classroom, the teacher searches for student's understanding of the concepts and then structures opportunities for students to refine or revise these understandings by posing contradictions, presenting new information, asking questions, encoring research, and/or engaging students in inquired designed to challenge current concepts." Thus in constructivist science classroom, the teacher is not the sage on the stage but mentor or guide on side of students, who not provide instruction to passive students but designing learning situations for the active learner of science. There are ten basic guiding principles of constructivist thinking that educators must keep in mind: 1) learning is an active process in which the student constructs meaning, 2)People learn to learn3) Learning involves language 4) Learning is a social activity 5)Learning is contextual 6) The act of constructing meaning is mental 7) Everyone needs knowledge to learn 8)Learning is not the passive acceptance of knowledge it takes work 9) Motivation is a major aspect of learning and 10) It takes time to learn.

Donald R. Cruickshank (2006) states several learning activities that are considered necessary in implementing constructivism approach such as: collaboratively formulating questions, explaining phenomenon, addressing complex issues, and resolving problems. One of the important factors that should be considered in implementing constructivism approach is the student support and assistance in form of the following methods: prompts or clues, explanations, demonstration, coaching and adding learning resources. The objective of implementing constructivism approach in learning activities is to provide students with the specific abilities in searching, understanding, and applying knowledge and skill. 
Marlowe and Page (2005) state that there are at least four points regarding to the constructivist learning theory the first is constructivism refers to the process of constructing knowledge by the learners. Learning is describe as the active action. The second point is dealing with the process of thinking and analyzing that learning is not merely the accumulation of memory but it is the process of activating critical thinking and analyzing. The next point is the significant of learning process regarded to constructing understanding and applying the knowledge not just repetition it. The last point is that constructivism theory is designed for establishing active learning process not passive.

\section{Constructivism Learning Theory in Science}

Cruickshank (2006) notes several characteristics of the constructivism approach to learning such as: (a) Active learning; (b) Learner should engage in authentic and contextual activities; (c) Learning activities should be interesting and challenging; (d) Bridging; (e) Learner should think about what is being learned; (f) Learning takes place best in communities of learners; (g) Teacher facilitate the acquisition process of information; (h) Teachers must provide learners with assistance or scaffolding. Students has to be an active person in constructing the meaning of the concepts. They have to interact with other students and also the teacher to explore the concepts. In addition, they must involve in contextual situation to apply the concepts. Learning events should be designed related to students' learning needs. Learning process should provide a chance for students to solve the problems. Bridging-connecting old and new learned concepts - is necessary to facilitate students learning process. Students will learn better if they know what has been learned. Interaction among the students is required to provide chances for them to share and build meaningful knowledge. Scaffolding - providing systematic help to students during their learning process - is necessary in implementing constructivism approach. Teachers in this matter has a significant as a facilitator. According to the constructivists, learning is viewed as an active process. The students have to search a meaningful knowledge and information to be applied in contextual situation. The students are not passive learning object. They must be able to construct knowledge by connecting the instructional content to previous learned concepts. Learning is an active process of finding, understanding, and implementing knowledge to solve contextual problems. The students must be able to construct their own knowledge and skills. They must be highly competent in gaining new comprehension of their learning experiences. According to the constructivists, learning is viewed as an active process. The students have to search a meaningful knowledge and information to be applied in contextual situation. The students are not passive learning object. They must be able to construct knowledge by connecting the instructional content to previous learned concepts. Learning is an active process of finding, understanding, and implementing knowledge to solve contextual problems.

Teaching methods based on constructivist views are very useful to help students' learning. The following are practices derived from cognitive psychology that can help students understand, recall and apply essential information, concepts and skills. They are used to make lessons relevant, activate students' prior knowledge, help elaborate and organize information, and encourage questioning. Important concepts from this perspective are (Slavin, 1994) :

1. Advanced organizers: general statements given before instruction that relate new information to existing knowledge to help students process new information by activating background knowledge, suggesting relevance, and encouraging accommodation;

2. Analogies: pointing out the similarities between things that are otherwise unlike, to help students learn new information by relating it to concepts they already have; and

3. Elaboration: the process of thinking about new material in a way that helps to connect it with existing knowledge. 
Constructivism sees learning as a dynamic and social process in which learners actively construct meaning from their experiences in connection with their prior understandings and the social setting (Driver, Asoko, Leach, Mortimer \& Scott, 1994). The constructivist view of learning argues that students do not come to the science classroom empty-headed but arrive with lots of strongly formed ideas about how the natural world works. In the view of constructivists, pupils should no longer be passive recipients of knowledge supplied by teachers and teachers should no longer be purveyors of knowledge and classroom managers (Fosnot, 1996). From this perspective, learning is a process of acquiring new knowledge, which is active and complex. This is the result of an active interaction of key cognitive processes (Glynn, Yeany \& Britton, 1991). It is also an active interaction between teachers and learners, and learners try to make sense of what is taught by trying to fit these with their own experience. From this perspective, learning is a process of acquiring new knowledge, which is active and complex. This is the result of an active interaction of key cognitive processes (Glynn, Yeany \& Britton, 1991). It is also an active interaction between teachers and learners, and learners try to make sense of what is taught by trying to fit these with their own experience.

Though Wilson (2000) suggested science educators need to look beyond the confines of cognitive psychology in developing pupils' understanding of scientific concepts, the four immediate accessible points she suggested for practicing teachers to consider in teaching concepts to pupils also rooted with constructivist teaching, these were: recognizing what pupils already know; teach fewer concepts; improve continuity across key stages and progression of the development of concepts. Pupils are exposed to scientific concepts at a much earlier stage in their education; and, acknowledge the diversity of learners.

The constructivist view of learning holds that students do not come to science class with an empty head but arrive with many well-formed ideas about how the natural world works. In the constructivist view, students can no longer be passive recipients of the knowledge provided by the teacher and the teacher is no longer a supplier of knowledge and class managers. From this perspective, learning is a process of acquiring new knowledge, which is active and complex. It is the result of the active interaction of the main cognitive processes. It is also an active interaction between teacher and students, and students try to understand what is being taught by trying to adapt it to their own experiences.

For Piaget, children and adults use mental patterns (schemes) to guide behavior or cognition, and interpret new experiences or material in relation to existing schemes (Piaget, 1978). However, for new material to be assimilated, it must first fit an existing scheme. Verysimilarly, for Ausubel, meaningful information is stored in networks of connected facts orconcepts referred to as schemata. New information, which fits into an existing schema, is more easily understood, learned, and retained than information that does not fit into an existing schema (Slavin, 1988). For both theorists then, new concepts that are well anchored by, or attached to existing schemata (or schemes) will be more readily learned and assimilated than new information relating to less established schemata. The same holds true for information not attached to any schemata at all (e.g., the case with compartmentalized, or rote learning).

When a learner encounters situations in which a learner's existing schemes cannot explain new information, existing schemes must be changed or new ones made. This process, as termed by Piaget, is accommodation. The condition leading to accommodation is known as disequilibration; that is, the state encountered by a learner in which new information does not fit an existing scheme (Slavin, 1988). To restore balance to the cognitive system, new schemes are developed, or old ones modified, until equilibration is reached, and the new information accommodated into the learner's view of the world.

Learning for understanding in classroom requires well-designed hands on, as well as minds on, activities that challenge students' existing conceptions leading students to reconstruct their 
personal theories. As Driver, Asoko, Leach, Mortimer, Scott (1994) pointed out the view of scientific knowledge as socially constructed and validated has crucial implications for science education. Scientific entities and concepts are unlikely to be discovered by individuals through their empirical enquiry. Therefore learning science involves being initiated into the ideas and procedures of scientific community and making these ideas and practices meaningful at an individual level. It is a perspective on science learning as a process of enculturation rather than discovery, arguing that empirical study of the nature will not reveal scientific knowledge because scientific knowledge is discursive in nature. As a science educator, we should emphasize the quality of our students' understandings rather than just surface learning or their test scores. Conceptual understanding is crucial and it should be a focus of our interest in science teaching, we need to promote conceptual learning over rote memorization. Science teachers should call attention to the process of science rather than just the content, because students who understand the process are better prepared to acquire science content on their own (Basili, \& Sanford, 1991).

Today's teachers should not just consider themselves teachers but also students of learning Constructivism similarly provides a sound theoretical foundation for explicating science pedagogy. This brief discussion focuses on alternative conceptions, conceptual change teaching, and cooperative learning. Summarizing and interpreting the research literature on alternative conceptions in science, Wandersee, Mintzes, and Novak (1994) pointed out thatthe cornerstone of this body of research rests on the evidence-documented claim that students harbor a wide variety of alternative conceptions about objects and events when they enter formal instruction in science. Moreover, the origins of these alternative conceptions lie in students' diverse personal experiences, which include observation, perception, culture, language, prior teachers' explanations, and prior instructional materials. Students hold tenaciously onto these alternative conceptions in the face of traditional formal instruction. Finally, all of this prior knowledge interacts with whatever is presented in formal instruction, resulting in a wide variety of unintended learning outcomes by students. The integrated principles of constructivism accounts very well for these claims. Recounting them, first, knowledge is actively built up from within by individuals and by communities. Second, language-based social interactions are central to the building of knowledge by individuals and communities. Third, the character of cognition and a language, which in employed to express cognition, is functional and adaptive. Fourth, the purpose of cognition and language is to bring coherency to an individual's world of experience and a community's knowledge base, respectively. Students have worked diligently over a long period of time to organize their experiential worlds, and substantial reorganization similarly requires diligent thought and time. Innovations in science pedagogy such as conceptual change teaching strategies hold much promise for dealing with students' alternative conceptions.

\section{CONCLUSION}

Constructivism is the active learning process in order to achieve the knowledge. Constructivist teaching is based on the belief that learning occurs as learners are actively involved in a process of meaning and knowledge construction rather than passively receiving information. Learners are the makers of meaning and knowledge. constructivism by realizing the ideal four principles of learning are learning is determined by what we already know, the significant of elaborate new ideas or information, learning designed to invent something new such as ideas rather than mechanically accumulating facts, and meaningful learning occurs 
through rethinking old ideas and coming to new conclusions about new ideas which conflict with our old ideas.

Constructivism learning theory is a theory that gives freedom to humans who want to learn or look for their needs with the ability to find their wants or needs with the help of others, so this theory provides activeness for humans to learn to find their own competencies, knowledge, or technology and other things that needed to develop itself. Constructivism learning theory holds that people produce knowledge and form meaning based on their experiences. In constructivism, learning is represented as a constructive process in which students build internal illustrations of knowledge, interpretations of personal experiences.

Constructivism teaching is based on learning that occurs through the active involvement of students in the construction of meaning and knowledge. Teaching science from a constructivist perspective aims to give students knowledge of science in such a way that they not only understand the concepts and principles of science, but also the significance of science learning.

Constructivism as an approach to learning that emphasizes students building their knowledge from the experience gained so that this approach allows for effective learning of science. According to the constructivists, learning is viewed as an active process. The students have to search a meaningful knowledge and information to be applied in contextual situation. The students are not passive learning object. They must be able to construct knowledge by connecting the instructional content to previous learned concepts. Learning is an active process of finding, understanding, and implementing knowledge to solve contextual problems.

\section{REFERENCES}

Brooks, J. G., \& Brooks, M. G. (1993). In Search of Understanding: The Case For Constructivist Classrooms. Alexandria, VA: Association for supervision and Curriculum Development.

Carin, A. A., \& Sund, R. B. (1989). Teaching science through discovery (6th ed.). Columbus, OH: Merrill Publishing Co.

Christie, A. (2005). Constructivism and its implications for educators.

Cruickshank, Donald R. Deborah B. Jenkin, \& Kim K Metcalf. (2006) The Act of Teaching. New York: McGraw Hill.

Driver, R., Asoko, H., Leach, J., Mortimer, E., \& Scott, P. (1994). Constructing Scientific Knowledge in the Classroom. Educational Researcher, 23, 5-12

Glynn, S. M., Yeany, R. H., \& Britton, B. K. (1991). A constructive view of learning science. In S. M. Glynn, R. H. Yeany, \& B. K. Britton (Eds.), The psychology of learning science (pp. 319). Lawrence Erlbaum Associates, Inc

Marlowe, B. A. \& Page, M. L. (2005). Creating and sustaining the constructivist classroom (2nd ed.). Thousand Oaks, CA: Corwin Press.

Posner, G. J., Strike, K. A., Hewson, P. W., \& Gertzog, W. A. (1982). Accommodation of a scientific conception: Toward a theory of conceptual change. Science Education, 66(2) 
Email : editorijhess@gmail.com

Robert E. Slavin. (1994). A Practical Guide to Cooperative Learning. Boston: Allyn and Bacon,.

Robert A. Wilson. 2004.Boundaries of the mind: The individual in the fragile sciencesCognition RA Wilson Cambridge University Press

Wing, W \& Mui, SO. (2002). Constructivist teaching in science. Asia-Pacific Forum on Science Learning and Teaching, Volume 3, Issue 1, Article 1.

Zed, Mestika. 2003. Metode Penelitian Literatur. Jakarta : Yayasan Obor Indonesia. 